\title{
EHMTI-0249. Headache attributed to hypertension in chronic migraine patients
}

\author{
O Grosu*, I Moldovanu, S Odobescu, L Rotaru \\ From 4th European Headache and Migraine Trust International Congress: EHMTIC 2014 \\ Copenhagen, Denmark. 18-21 September 2014
}

\section{Background}

Hypertension is frequent in chronic migraine patients and could be a factor that promotes chronification (Bigal, 2008). In these patients could be a secondary headache named "headache attributed to hypertension".

\section{Aim}

To detect the presence of "headache attributed to hypertension" in chronic migraine patients with high blood pressure (HBP).

\section{Method}

Study sample include 60 chronic migraine patients with associated arterial hypertension (MwHBP) and 30 patients with hypertension without migraine $(\mathrm{HBPw} / \mathrm{oM})$. All the patients underwent neurological examination, ambulatory blood pressure monitoring. Headache was established according to IHS criteria $(2004,2013)$.

\section{Results}

In the MwHBP group $65 \%$ of patients presented a second type of headache corresponding to "headache attributed to hypertension" criteria compared to $33 \%$ in the HBPw/oM group. This type of headache in MwHBP group was unilateral $(60 \%$ vs. $23.1 \%, \mathrm{p}<0.05)$, pulsating $(60 \%$ vs. $17.9 \%$, $\mathrm{p}<0.05)$, in any part of the day ( $80 \%$ vs. $23.1 \%, \mathrm{p}<0.05)$, with the combination of two or more associated symptoms (100\% vs. $0 \%$ ) compared with HBPw/oM group - predominantly on the morning, with isolated associated symptoms (30\% - just photophobia vs. $0 \%, 40 \%$ - just phonophobia vs. $0 \%, 30 \%$ - just nausea vs. $0 \%, \mathrm{p}<0.05)$.

\section{Conclusion}

In the chronic migraine patients with associated hypertension could be detected two types of headaches. The

Neurology, Institute of Neurology and Neurosurgery, Chisinau, Moldova first one is migraine and the second - "headache attributed to hypertension", which is more frequent than in the hypertension without migraine group (65\% vs. $33 \%)$ and preserved the migrainous features.

No conflict of interest.

Published: 18 September 2014

doi:10.1186/1129-2377-15-S1-C18

Cite this article as: Grosu et al:: EHMTI-0249. Headache attributed to

hypertension in chronic migraine patients. The Journal of Headache and Pain 2014 15(Suppl 1):C18.

\section{SpringerOpen $^{\circ}$}

C 2014 Grosu et al; licensee Springer. This is an Open Access article distributed under the terms of the Creative Commons Attribution License (http://creativecommons.org/licenses/by/2.0), which permits unrestricted use, distribution, and reproduction in any medium, provided the original work is properly cited.
Submit your manuscript to a SpringerOpen ${ }^{\circ}$ journal and benefit from:

- Convenient online submission

- Rigorous peer review

- Immediate publication on acceptance

- Open access: articles freely available online

- High visibility within the field

Retaining the copyright to your article

Submit your next manuscript at $>$ springeropen.com 